\title{
ASTAXANTHIN MODIFIES CLASTOGENIC EFFECTS OF IONIZING RADIATION IN VITRO IN PERIPHERAL BLOOD LYMPHOCYTES OF THE PERSONS RECOVERED FROM ACUTE RADIATION SICKNESS
}

\author{
D.A. Kurinnyi ${ }^{1, *}$, S.R. Rushkovsky ${ }^{2}$, O.B. Dybska ${ }^{1}$, G.V. Dubrovina ${ }^{1}$, M.A. Pilinska ${ }^{1}$ \\ ${ }^{1}$ State Institution "National Research Center for Radiation Medicine of the National Academy of Medical \\ Sciences of Ukraine”, Kyiv 04050, Ukraine \\ ${ }^{2}$ Institute of Biology and Medicine, Taras Shevchenko Kyiv National University, Kyiv 01601, Ukraine
}

\begin{abstract}
Aim: To assess radioprotective activity of astaxanthin toward radiation-induced in vitro cytogenetic effects in human peripheral blood lymphocytes (PBL). Materials and Methods: PBL from the cleanup workers exposed to ionizing radiation at high doses in 1986 during accident on Chornobyl nuclear power plant and who were diagnosed with acute radiation sickness of the first and second degrees, were cultured in vitro. Astaxanthin was added into the culture medium at a final concentration of $20.0 \mu \mathrm{g} / \mathrm{ml}$, prior to $\gamma$-irradiation of PBL in vitro at a dose of $1 \mathrm{~Gy}$. The slides of metaphase chromosomes were analyzed. Results: Astaxanthin demonstrated considerable radioprotective effect in irradiated PBL manifested in significantly decreased levels of unstable cytogenetic markers of radiation exposure (dicentrics and centric rings). Conclusion: The data evidence on radioprotective capacity of astaxanthin toward radiation-induced cytogenetic effects in vitro in PBL of liquidators irradiated during Chornobyl nuclear power plant accident. This article is a part of a Special Issue entitled "The Chornobyl Nuclear Accident: Thirty Years After". Key Words: astaxanthin, human peripheral blood lymphocytes, chromosomal aberrations, $\gamma$-irradiation, acute radiation sickness, radioprotective effect.
\end{abstract}

In April 26, 1986 the greatest technological catastrophe in human history - the nuclear accident at the Chornobyl nuclear power plant (CNPP) took place. In Ukraine 222,498 persons received the status of liquidators of this catastrophe. Among liquidators, who performed emergency work on the fourth power unit and received in the early days of the accident doses from 1 to $12 \mathrm{~Gy}, 134$ cases of acute radiation sickness (ARS) were diagnosed [1]. Exposure of humans to ionizing radiation is manifested primarily by the damage of the cell genome, which is one of the driving forces for various pathologies with a genetic component, including the malignant transformation of cells [2]. Therefore, protection of human genome in persons exposed to ionizing radiation is extremely important task.

One of the perspective radioprotectors is astaxanthin - a natural carotenoid from xanthophyll group. It has low toxicity, high antiradical and antioxidant activity, the ability to pass through the cell membrane and reach the genetic apparatus in the cell nucleus [3-6]. However, despite a number of investigations of various aspects of biological effects of astaxanthin, its possible radioprotective properties are still unknown.

It is widely accepted that the frequency of chromosomal aberrations in human peripheral blood lymphocytes (PBL) specific for ionizing radiation could serve as the reliable indicator of radiation mutagenesis intensity. So, exactly this criterion was chosen by us to assess possible gene protective properties of astaxanthin. Previously we discovered the ability of astaxanthin to decrease radiation-induced level of chromosomal

Submitted: November 23, 2016.

*Correspondence: E-mail: kourinniy@gmail.com Abbreviations used: ARS - acute radiation sickness; CNPP - Chornobyl nuclear power plant; PBL - peripheral blood lymphocytes. aberrations in somatic cells of conditionally healthy volunteers [7]. In present study, we have evaluated both background (output) frequency and spectrum of chromosomal aberrations in PBL and cytogenetic effects of ionizing radiation in vitro per se and combined with astaxanthin to estimate its radioprotective potential even for persons who recovered from ARS.

A voluntary cytogenetic examination (under conditions of informed consent) was performed in two liquidators (V. and B. aged 73 and 76, respectively), in whom ARS of first and second degrees of severity caused by radiation exposure during emergency work at the reactor number four of CNPP was diagnosed in the NRCRM clinic in 1987. Official documented radiation doses (2.0 and 2.8 Gy, respectively) for these persons were established in 1986. Since 1987 both liquidators are disabled persons of group II and have been annually examined and treated in the NRCRM clinic. In the past cytogenetic observations of these persons were performed by us several times - patient V. in 1996; patient B. in 1987, 1992, and 1997. In 2016 not only background (output) frequency and spectrum of chromosomal aberrations in PBL was defined, but also cytogenetic effect under separate and compatible action of astaxanthin and ionizing radiation in vitro.

For cytogenetic studies a conventional classical test system, human PBL cultured for $48 \mathrm{~h}$, was used. Astaxanthin (Sigma, USA) was introduced into the culture medium in an optimal concentration of $20.0 \mu \mathrm{g} / \mathrm{ml}$, defined during our previous studies, at early $G_{0}$ stage of the first mitotic cycle before beginning the PBL incubation, prior to $\gamma$-irradiation using emitter IBL-237C (with the capacity of $2.34 \mathrm{~Gy} / \mathrm{min}$ ) at a dose of $1.0 \mathrm{~Gy}$ [7]. The cytogenetic analysis accounted all aberrations of chromatid (single fragments, chromatid exchanges) 
and chromosome (free double fragments, acentric rings, dicentric and ring chromosomes, abnormal monocentrics) types, which can be recognized on uniformly stained slides of metaphase chromosomes [8].

The results of cytogenetic analyses are shown in Tables 1 and 2. The data presented in Table 1 demonstrate a gradual decline over time of the overall frequency of chromosomal aberrations in the exposed individuals, mainly due to the elimination of specific cytogenetic markers of radiation exposure - as unstable (dicentrics and centric rings) as well as stable (abnormal monocentrics) aberrations of chromosome type. However, under the cytogenetic survey in 2016, the tendency for increased level of free acentrics (single and double fragments) was found, which permit to suggest the development of hidden chromosomal instability [9].

For detection of the possible hidden chromosomal instability and comparison of individual radiosensitivity, the radiation in vitro exposure of $\mathrm{PBL}$ cultures obtained from surveyed persons was conducted. As seen from the data presented in Table 2, under in vitro irradiation of PBL cultures the elevation of cytogenetic effects up to $25.71 \pm 2.61$ and $32.56 \pm 2.69$ aberrations per 100 metaphases in liquidators B. and V., respectively, was revealed. In both persons chromosome types of aberrations were dominant, which is typical for chromosomal mutagenesis under the radiation exposure in $G_{0}$ phase of mitotic cycle. In the irradiated in vitro cultures the individual frequencies of unstable radiogenic markers (total dicentric and ring chromosomes) increased up to $18.22 \pm 2.30$ and $22.04 \pm 2.38$ per 100 metaphases in patients $B$. and V., respectively. Also, the frequency of chromosome type acentrics increased significantly (total number of double fragments and acentric rings increased up to $5.71 \pm 1.38$ and $9.20 \pm 1.65$ per 100 metaphases in liquidators B. and V., respectively). These data may indicate the rise of radiosensitivity in "high-doses liquidators" in delayed terms after irradiation. It should be noted that the data on in vitro tests of liquidator $\mathrm{V}$. with lower official dose and lower ARS degree, indicated his higher radiosensitivity.

Results of astaxanthin impact on radiation-induced in vitro cytogenetic effects are presented in Table 2 , and showed the significant $(p<0.01)$ reduction of the total frequency of chromosomal aberrations (from $25.71 \pm$ 2.61 to $15.30 \pm 2.09$ and from $32.56 \pm 2.69$ to $18.42 \pm$ 2.12 per 100 metaphases in patients B. and V., respectively) due to significant $(p<0.01)$ decrease of classical radiogenic markers (dicentric and ring chromosomes) - from $18.22 \pm 2.30$ to $4.08 \pm 1.89$ and from $22.04 \pm 2.38$ to $7.89 \pm 1.54$ per 100 metaphases in patients B. and V., respectively. The effectiveness of radioprotective activity of astaxanthin according to these indicators was $\sim 78 \%$ and $64 \%$ in patients B. and V., respectively under $\sim 82 \%$ in unexposed group of healthy donors. However, almost unchanged $(p>0.05)$ total frequencies of acentrics ( $7.49 \pm 1.57$ vs $9.86 \pm 1.73$ and $9.21 \pm 1.65$ vs $10.43 \pm 1.75$ per 100 metaphases in patients B. and V., accordingly) and appearance of abnormal monocentrics in liquidator $B$. (1.36 \pm 0.67 per 100 metaphases) may testify both persistence of hidden chromosomal instability in remote terms after high-dose irradiation and increase of individual radiosensitivity in particular because of multiple $\mathrm{X}$-ray examinations of ARS convalescences for a long time.

It should be noted that radioprotective activity of astaxanthin in PBL of persons recovered from ARS is lower than in PBL of healthy persons (total frequency of chromosome type aberrations is $66 \%$ vs $43 \%$ and $48 \%$, respectively) (see Table 2). These data suggest that activity of the repair systems in post-ARS persons is reduced even in delayed terms following high-dose irradiation.

\section{REFERENCES}

1. National Report «Thirty years of Chornobyl catastrophe: Radiological and health effects» [monograph on the Internet]. Kyiv: State Institution «National Research Center for Radiation Medicine of National Academy of Medical Sciences of Ukraine» [cited 2016 Nov 22]. Available from: http://www.nrcrm.gov.ua.

Table 1. The dynamics of cytogenetic effects in PBL of persons recovered from ARS at different terms after irradiation

\begin{tabular}{|c|c|c|c|c|c|c|c|c|c|c|c|c|}
\hline \multirow{2}{*}{$\begin{array}{l}\text { Indi- } \\
\text { vidual } \\
\text { code }\end{array}$} & \multirow{2}{*}{$\begin{array}{c}\text { Year } \\
\text { of exami- } \\
\text { nation }\end{array}$} & \multirow{2}{*}{$\begin{array}{c}\begin{array}{c}\text { Frequency } \\
\text { of aberrant } \\
\text { cells, } \%\end{array} \\
\mathrm{M} \pm \mathrm{SE}\end{array}$} & \multirow{2}{*}{$\begin{array}{l}\text { Chromosomal } \\
\text { aberrations, } \\
\text { per } 100 \text { cells } \\
M \pm m\end{array}$} & \multicolumn{3}{|c|}{$\begin{array}{l}\text { Frequency of chromatid type } \\
\text { of aberrations, per } 100 \text { cells }\end{array}$} & \multicolumn{6}{|c|}{ Frequency of chromosome type of aberrations, per 100 cells } \\
\hline & & & & $\begin{array}{c}\text { Single } \\
\text { fragments }\end{array}$ & $\begin{array}{l}\text { Exchan- } \\
\text { ges }\end{array}$ & Total & $\begin{array}{c}\text { Double } \\
\text { fragments }\end{array}$ & Dicentrics & $\begin{array}{l}\text { Centric } \\
\text { rings }\end{array}$ & $\begin{array}{c}\text { Abnormal } \\
\text { monocentrics }\end{array}$ & $\begin{array}{l}\text { Acentric } \\
\text { rings }\end{array}$ & Total \\
\hline \multirow[t]{4}{*}{ B. } & 1987 & $11.50 \pm 2.26$ & $14.00 \pm 2.45$ & 1.00 & 0 & 1.00 & 3.00 & 1.50 & 1.00 & 6.50 & 1.00 & 13.00 \\
\hline & 1992 & $5.00 \pm 1.61$ & $5.00 \pm 1.61$ & 1.00 & 0 & 1.00 & 1.50 & 0.50 & 0 & 2.50 & 0 & 4.50 \\
\hline & 1997 & $2.00 \pm 0.99$ & $2.00 \pm 0.99$ & 1.50 & 0 & 1.50 & 0.50 & 0 & 0 & 0 & 0 & 0.50 \\
\hline & 2016 & $3.67 \pm 1.20$ & $3.67 \pm 1.20$ & 2.45 & 0 & 2.45 & 1.22 & 0 & 0 & 0 & 0 & 1.22 \\
\hline \multirow[t]{2}{*}{ V. } & 1996 & $7.50 \pm 1.86$ & $8.00 \pm 1.92$ & 0.50 & 0 & 0.50 & 0 & 2.50 & 0.50 & 4.50 & 0 & 7.50 \\
\hline & 2016 & $3.87 \pm 1.01$ & $3.87 \pm 1.01$ & 1.93 & 0 & 1.93 & 1.66 & 0.28 & 0 & 0 & 0 & 1.94 \\
\hline
\end{tabular}

Table 2. Cytogenetic effects in PBL of persons recovered from ARS after $\gamma$-irradiation in vitro at a dose of 1 Gy per se and combined with astaxanthin

\begin{tabular}{|c|c|c|c|c|c|c|c|c|c|c|c|c|}
\hline \multirow{2}{*}{$\begin{array}{l}\text { Indi- } \\
\text { vidual } \\
\text { code }\end{array}$} & \multirow{2}{*}{$\begin{array}{l}\text { Treat- } \\
\text { ment }\end{array}$} & \multirow{2}{*}{$\begin{array}{c}\begin{array}{c}\text { Frequency } \\
\text { of aberrant } \\
\text { cells, } \%\end{array} \\
\mathrm{M} \pm \mathrm{SE}\end{array}$} & \multirow{2}{*}{$\begin{array}{l}\text { Chromosomal } \\
\text { aberrations, } \\
\text { per } 100 \text { cells } \\
M \pm m\end{array}$} & \multicolumn{3}{|c|}{$\begin{array}{l}\text { Frequency of chromatid type } \\
\text { of aberrations, per } 100 \text { cells }\end{array}$} & \multicolumn{6}{|c|}{ Frequency of chromosome type of aberrations, per 100 cells } \\
\hline & & & & $\begin{array}{c}\text { Single } \\
\text { fragments }\end{array}$ & $\begin{array}{l}\text { Exchan- } \\
\text { ges }\end{array}$ & Total & $\begin{array}{c}\text { Double } \\
\text { fragments }\end{array}$ & Dicentrics & $\begin{array}{l}\text { Centric } \\
\text { rings }\end{array}$ & $\begin{array}{c}\text { Abnormal } \\
\text { monocentrics }\end{array}$ & $\begin{array}{l}\text { Acentric } \\
\text { rings }\end{array}$ & Total \\
\hline B. & Irr & $25.0 \pm 2.58$ & $25.71 \pm 2.61$ & 1.78 & 0 & 1.78 & 5.71 & 16.43 & 1.79 & 0 & 0 & 23.93 \\
\hline B. & Irr + A & $14.62 \pm 2.06$ & $15.30 \pm 2.09$ & 1.70 & 0 & 1.70 & 8.16 & 4.08 & 0 & 1.36 & 0 & 13.60 \\
\hline V. & Irr & $30.92 \pm 2.65$ & $32.56 \pm 2.69$ & 1.32 & 0 & 1.32 & 7.89 & 18.75 & 3.29 & 0 & 1.31 & 31.24 \\
\hline V. & Irr + A & $16.44 \pm 2.12$ & $18.42 \pm 2.22$ & 2.30 & 0 & 2.30 & 7.56 & 7.24 & 0.65 & 0 & 0.67 & 16.12 \\
\hline * & Irr & $22.93 \pm 1.19$ & $24.55 \pm 1.22$ & 1.54 & 0 & 1.54 & 6.47 & 12.80 & 2.76 & 0.49 & 0.49 & 23.02 \\
\hline * & $\operatorname{Irr}+\mathrm{A}$ & $7.82 \pm 0.72$ & $8.48 \pm 0.75$ & 0.72 & 0 & 0.72 & 4.67 & 2.37 & 0.43 & 0.22 & 0.07 & 7.76 \\
\hline
\end{tabular}

Note: *unexposed group of comparison $(\mathrm{n}=4)$ [7]; Irr - exposition to $\gamma$-irradiation; Irr + A - exposition to $\gamma$-irradiation and supplementation with astaxanthin. 
2. Lengauer C, Kinzler KW, Vogelstein B. Genetic instabilities in human cancers. Nature 1998; 396: 643-9.

3. Guerin M, Huntley ME, Olaizola M. Haematococcus astaxanthin: applications for human health and nutrition. Trends Biotechnol 2003; 21: 210-6.

4. Nishida Y, Yamashita E, Miki W. Quenching activities of common hydrophilic and lipophilic antioxidants against singlet oxygen using chemiluminescence detection system. Carotenoid Sci 2007; 11: 16-20.

5. Kamath BS, Srikanta BM, Dharmesh SM, et al. Ulcer preventive and antioxidative properties of astaxanthin from Haematococcus pluvialis. Eur J Pharmacol 2008; 590: $387-95$.

6. Kurihara H, Koda H, Asami S, et al. Contribution of the antioxidative property of astaxanthin to its protective effect on the promotion of cancer metastasis in mice treated with restraint stress. Life Sci 2002; 70: 2509-20.

7. Pilinska MA, Kurinnyi DA, Rushkovsky SR, Dybska OB. The impact of astaxanthin on radiation-induced chromosome aberrations in human peripheral blood lymphocytes in vitro. Visn Ukr Soc Genet Select 2016; 14: 52-7 (in Ukrainian).

8. Zakharov AF, Benyush VA, Kuleshov NP, Baranowska LI. Human Chromosomes: Atlas. M: Medicina, 1982. 263 p. (in Russian).

9. Pilinska MA, Dybsky SS, Dybska OB, et al. Peculiarities of induction and persistence of hidden chromosome instability in peripheral blood lymphocytes of persons occupationally exposed to ionizing radiation. Probl Radiac Med Radiobiol 2014; (19): 321-33. 